\title{
Protective Effects of Copper (I)-Nicotinate Complex Against Aflatoxicosis
}

\author{
Ahmed R. Shatat ${ }^{1, *}$, Heba M. Saad Eldien ${ }^{2}$, Muammar Y. Nassar ${ }^{4}$, Amany O. Mohamed ${ }^{3}$, Abdel \\ Haleem M. Hussein ${ }^{1}$, Abu-Bakr A. El-Adasy ${ }^{1}$, Ahmed A. Khames ${ }^{1}$ and Ahmed Y. Nassar ${ }^{3}$ \\ ${ }^{I}$ Department of Chemistry, Faculty of Science-Al-Azhar University-Assiut Branch-Egypt \\ ${ }^{2}$ Department of Histology, Faculty of Medicine- Assiut University-Egypt \\ ${ }^{3}$ Department of Biochemistry, Faculty of Medicine-Assiut University-Egypt \\ ${ }^{4}$ Department of Biochemistry, Dongola University- Sudan
}

\begin{abstract}
Aflatoxicosis mostly leads to serious clinical signs of malnutrition, growth retardation, and impairment of utilization of nutrients, immunosupression, liver diseases and cancer. Detoxification or prevention of such toxicity is interesting to researchers in change field. In pursuit for an approach, the synthetic copper(I)- nicotinate complex has been evaluated against the traditional Butylated hydroxy toluene (BHT) for possible protective effects as a food additive in induced aflatoxicosed animals. Induction of toxicity in adult rats by $\mathrm{AFB}_{1} 60 \mu \mathrm{g} / \mathrm{kg}$ body weight divided on three times a week for consecutive five weeks resulted in marked hepatic necrosis, collagen fibers around portal tract and iron deposits as well as features of general cellular collapse and cirrhosis. The protective effects were tested on two animal groups by associate doses of BHT (0.05 mg / kg B.W.) in one group and copper (I) nicotinate complex $(0.4 \mathrm{mg} / \mathrm{kg} \mathrm{B}$.W.) in the other. Results showed, in both groups, almost normal histological as well as biochemical markers especially those treated with the copper complex, which suggests that anti-inflammatory copper complex can be used as a protective agent against aflatoxicosis when used in doses resemble those used in pharmaceutical vitamin supplements.
\end{abstract}

Keywords: Aflatoxicosis, Copper (I) Nicotinate Complex, Antioxidant chemoprotectant, Butylated hydroxytoluen (BHT), Malondialdehyde (MDA).

\section{INTRODUCTION}

Biological mycotoxicosis depends mainly on the type of mycotoxin [1], as the acute or chronic intoxication by $\mathrm{AFB}_{1}$ is reflected according to the level of metabolite 8,9-epoxide [2]. The bioactivation product, epoxide, is the most known genotoxic product of $\mathrm{AFB}_{1}$ [3]. Proteins that bind with aflatoxin $\mathrm{B}_{1}$ or its metabolites act as reservoir that sustains exposure for aflatoxicosis [4-6]. Evidence has been accumulating regarding the development of human hepatocellular carcinoma $\mathrm{HCC}$ with respect to $\mathrm{AFB}_{1}$-epoxide where the P53 tumor suppressor gene and more specifically, codon 249 of this gene were seriously affected [7]. Butylated hydroxy toluene is one of the most known food additives antioxidant that showed a versatile chemoprotective agent against mammary and liver cancer induced by several carcinogenic chemicals including $\mathrm{AFB}_{1}$ [8-10]. In mammals, the most important mechanism of $\mathrm{AFB}_{1}$-epoxide detoxification is attributed to the high affinity of glutathioneS-tranferase towards the more potent exo-epoxide derivation [11]. Such an affinity is proven to be promoted by the antioxidant butylated hydroxy derivatives $[12,13]$. Generally, antioxidants may impact their anti-carcinogenic property by inducing cellular detoxification pathway $[14$,

*Address correspondence to this author at the Al- Azhar University, Assiut Branch, Faculty of Science, Chemistry Department, Egypt;

Tel: 00201006785228; E-mail : ahmedshatat82@yahoo.com
15]. With regard to many of the biologically active copper chelating complexes [16] was the copper (I)- nicotinate that exhibiting antioxidant activity as well as therapeutic pharmaceutical activity against Newcastle diseases [17], anti-inflammatory effect on gastric ulcer [18], reduction of adverse effects of 5-Fluorouracil in patients with hepatocelluler carcinoma [19] and curative effect against induction of fatty liver in experimental animals [20].

\section{AIM OF THE WORK}

This work has been designed in order to evaluate the prophylactic effect of a bioactive copper (I) nicotinate complex as a food additive against aflotoxicosis. For this purpose the complex was given within the daily requirement of copper element, versus a commercially used phenolic derivative BHT.

\section{MATERIALS AND METHODS}

Fifty five Wister albino male rats ( $120-150$ g B.W.) were accommodated in appropriate healthy conditions and grouped into 4 groups: group I contained 15 animals for control measurements $\mathrm{G}_{\mathrm{I}}$, and 3 groups; 15 animals each, for experiment. The experimental groups were aflatoxicosed by orally ingested $\mathrm{AFB}_{1}(60 \mu \mathrm{g} / \mathrm{kg}$ B.W.), three times weakly for consecutive five weeks. The toxin as a pure sample was a gift from the Department of Botany, Mycology Center, Faculty of Science, Assiut University, Egypt. The First experimental group aflatoxicosed received no associate 
Table 1. Changes in Serum Total Protein Concentration (g/dl), Serum Albumin (g/dl), Serum ALT (U/L), serum AST (U/L), Serum GST $(\mathrm{nmol} / \mathrm{min} / \mathrm{ml})$, Serum Nitric Oxide $(\mu \mathrm{mol} / \mathrm{ml})$, Serum GSH $(\mathrm{nmol} / \mathrm{ml})$, Serum SOD (U/ml), Serum Ceruloplasmine $(\mathrm{mg} / \mathrm{dl})$ and Serum Total Thiols $(\mathrm{nM} / \mathrm{ml})$ in Control $\mathrm{G}_{\mathrm{I}}$, Aflatoxicosed Untreated $\mathrm{G}_{\mathrm{II}}$ and BHT $\mathrm{G}_{\mathrm{III}}$ and Copper Nicotinate $\mathbf{G}_{\text {IV }}$ Aflatoxin co-Treated Rats

\begin{tabular}{|c|c|c|c|c|}
\hline Parameters in Serum & $\begin{array}{c}\text { Group I } \\
\text { (Control), } \mathbf{n}=10\end{array}$ & $\begin{array}{c}\text { Group II } \\
(\mathrm{AFBI}), \mathbf{n}=\mathbf{1 5}\end{array}$ & $\begin{array}{c}\text { Group III } \\
(\mathrm{AFBI}+\mathrm{BHT}), \mathrm{n}=15\end{array}$ & $\begin{array}{c}\text { Group IV } \\
(\text { AFB1 + copper complex }), \mathbf{n}=15\end{array}$ \\
\hline total protein $(\mathrm{g} / \mathrm{dl})$ & $7.77 \pm 0.33$ & $4.17 \pm 0.96 * * *$ & $7.31 \pm 0.39$ N.S. & $7.48 \pm 0.22$ \\
\hline Albumin (g/dl) & $3.49 \pm 0.3$ & $1.94 \pm 0.8 * * *$ & $3.07 \pm 0.9$ N.S. & $3.28 \pm 0.09$ \\
\hline ALT (U/L) & $22.5 \pm 1.22$ & $50.25 \pm 0.95^{* *}$ & $26.45 \pm 1.42 *$ & $23.5 \pm 0.33$ \\
\hline AST (U.L) & $26.45 \pm 0.69$ & $70.08 \pm 2.31 * * *$ & $35.38 \pm 0.96^{* * * *}$ & $32.5 \pm 1.82 *$ \\
\hline total thiols $(\mathrm{nM} / \mathrm{ml})$ & $1.334 \pm 0.428$ & $1.305 \pm 0.55^{* * *}$ & $3.312 \pm 0.37 * * *$ & $3.827 \pm 1.62 *$ \\
\hline nitric oxide $(\mu \mathrm{mol} / \mathrm{ml})$ & $206.4 \pm 0.32$ & $238.7 \pm 0.99 * * *$ & $205.7 \pm 0.67$ & $198.6 \pm 1.19 * *$ \\
\hline $\mathrm{SOD}(\mathrm{U} / \mathrm{mL})$ & $5.5 \pm 8.7$ & $3.125 \pm 8.83^{* * *}$ & $5.75 \pm 9.45$ & $8 \pm 0.001 * * *$ \\
\hline GSH (nmol/ml) & $33.51 \pm 0.47$ & $21.12 \pm 1.33^{* * *}$ & $32.32 \pm 1.05$ & $33.57 \pm 0.88$ \\
\hline GST (nmol/min/ml) & $450.5 \pm 2.36$ & $325.3 \pm 2.98 * * *$ & $435.6 \pm 1.55^{*}$ & $446.2 \pm 3.72$ \\
\hline ceruloplasmine (mg/dl) & $50.28 \pm 1.36$ & $7.06 \pm 03.25 * * *$ & $49.63 \pm 02.54$ & $56.31 \pm 1.22 * *$ \\
\hline
\end{tabular}

Values are expressed as the mean $\pm \mathrm{SE}$ for (15) animals in each group.

$* \mathrm{p}<0.05 ; * * \mathrm{p}<0.01 ; * * * \mathrm{p}<0.001$ represent significant differences as compared to control animals (group I).

treatment; experimental control $\mathrm{G}_{\mathrm{II}}$. The second experimental group $\mathrm{G}_{\text {III }}$ animals were supplemented by BHT $(0.05 \mathrm{~g} / \mathrm{kg}$ B.W.) concomitant with $\mathrm{AFB}_{1}$ [21]. The phenolic BHT was purchased from Oxford Laboratory - Mumbai- 400002, CAS No. (128-73-0). The third experimental group $\mathrm{G}_{\mathrm{IV}}$ were treated by the synthesized copper(I)-nicotinate complex (400 $\mu \mathrm{g} / \mathrm{kg}$ B.W.) concomitant with $\mathrm{AFB}_{1}$ [22]. Experimental groups were scarified at the end of the time course of the experiment (5 weeks). Blood serum and liver tissue samples were collected for chemical analysis and histopathological examination. The tested biochemical parameters on the liver tissue were performed on homogenates (one gm/9 ml phosphate buffer at $\mathrm{pH}$ 7.4).

The biochemical testes included total protein [23], amino transferases ALT and AST (diagnostic kit by spectrum diagnostics, Egyptian company for biotechnology S.A.E.), nitric oxide [24], total thiols [25], superoxide dismutase [26], reduced glutathione [27], glutathione peroxidase [28], glutathione-S- tranferase [29], serum ceruloplasmine [30] and lipid peroxide [31]. Histological examination including iron staining was done by Perls' Prussian blue reaction according to Wang and Liao (2003)[32]; Wang, Zhou et al. (2004)[33], Masson's trichrome was done by Drury R and Wallington E.A. (1980)[34].

\section{RESULTS}

Serum total protein $(\mathrm{g} / \mathrm{dl})$ : Table $\mathbf{1}$, shows: the animals in $\mathrm{G}_{\mathrm{II}}$ showed dramatic reduction in serum total proteins that was highly significantly reduced vs normal control animals in $\mathrm{G}_{\mathrm{I}}$ $(\mathrm{p}<0.001)$. Intoxicated animals co-treated with BHT in $\mathrm{G}_{\mathrm{III}}$ showed that was non-significantly higher than normal. Similarly intoxicated animals co-treated with $\mathrm{Cu}$-nicotinate complex in $\mathrm{G}_{\mathrm{IV}}$ showed also non-significantly higher than normal control. Serum albumin level $(\mathrm{g} / \mathrm{dL})$ : Table 1 shows the aflatoxicosed animals $\mathrm{G}_{\text {II }}$ that was significantly lower than normal $(\mathrm{p}<0.001)$. Aflatoxicosed animals co-treated with BHT in $\mathrm{G}_{\mathrm{III}}$ showed non-significantly lower than normal controls. Similarly intoxicated animals co-treated with $\mathrm{Cu}$-nicotinate complex in $\mathrm{G}_{\mathrm{IV}}$ showed also non-significantly lower than normal controls. Serum ALT activity (U/L): Table 1, showed dramatic increased in $\mathrm{G}_{\mathrm{II}}$ than normal, $(\mathrm{p}<0.001)$. The level of serum ALT increased in $\mathrm{G}_{\mathrm{III}}$ which was still significant $(p<0.05)$. Aflatoxicosed animals of $\mathrm{G}_{\mathrm{IV}}$ was non-significantly than normal $(\mathrm{p}<0.05)$. Serum AST activity $(\mathrm{U} / \mathrm{L})$ : Table $\mathbf{1}$ shows the aflatoxicosed animals in $\mathrm{G}_{\mathrm{II}}$, that was dramatically significant increased over normal, $(p<0.001)$. AST level of $\mathrm{G}_{\mathrm{III}}$ it was still significantly higher than normal but is much less than control. The $\mathrm{G}_{\mathrm{IV}}$ group showed a reduced level of AST but it was still significantly higher than normal, $(\mathrm{p}<0.05)$. Serum total thiols concentration (nmol/ml): Table 1 illustrates the $\mathrm{G}_{\mathrm{II}}$ that was significantly reduced from normal control, $(p<0.001)$. The GIII that was still lower significantly than normal control, $(p<0.001)$. Similarly $\mathrm{G}_{\mathrm{IV}}$ showed a level of total thiols that was significantly lower than normal control, $(\mathrm{p}<0.05)$. Serum and hepatic tissue GSH $(\mathrm{nmol} / \mathrm{ml}),(\mathrm{nmol} / \mathrm{mg}$ protein): from Table $\mathbf{1}, \mathrm{G}_{\mathrm{II}}$ showed prominent reduction in serum GSH value that was highly significantly reduced than normal, $(p<0.001)$. Animals co-treated with BHT $\mathrm{G}_{\mathrm{III}}$ showed also reduction that was statistically not different from normal. Similarly $\mathrm{G}_{\mathrm{IV}}$ showed the same response that was also nonsignificantly deviated from normal value. In the hepatic tissue Table 2, $\mathrm{G}_{\mathrm{II}}$ animals showed significant reduction in hepatic tissue GSH value from normal, $(\mathrm{p}<0.001)$. Animals co-treated with BHT $G_{\text {III }}$ showed slightly reduction in the level GSH from the normal. While $\mathrm{G}_{\mathrm{IV}}$ animals showed also nonsignificantly different level from normal, $(\mathrm{p}<0.05)$. Total thiols of hepatic tissue (nmol/g): From Table 2, Aflatoxicosed untreated animals, $\mathrm{G}_{\mathrm{II}}$, showed significant reduction from normal animals $(p<0.001)$. The co-treated BHT animals in $\mathrm{G}_{\mathrm{III}}$ that was significantly lower than normal, but was about three times the value in untreated $\mathrm{G}_{\mathrm{II}}$. Similarly $\mathrm{G}_{\mathrm{IV}}$ showed improvement in hepatic tissue total thiols that was nonsignificantly different from normal, $(\mathrm{p}<0.001)$. Hepatic tissue lipid peroxidation level $(\mathrm{nmol} / \mathrm{g})$ : from Table 2 , it was found that significantly increased over normal in $\mathrm{G}_{\mathrm{II}}, \quad(\mathrm{p}<0.001)$. This level in $\mathrm{G}_{\text {III }}$ group was significantly elevated than normal $(p<0.05)$. G GV didn't show any significant elevation over 
Table 2. Changes in Hepatic Tissue Lipid Peroxide (nmol/g wt Tissue), Hepatic Tissue GsPx (nmol/min/mg Protein), Hepatic Tissue Total Thiols (nM/g Protein), Hepatic Tissue Nitric Oxide ( $\mu \mathrm{mol} / \mathrm{g}$ Protein), Hepatic Tissue GSH (nmol/mg Protein), and Hepatic Tissue GST (nmol/min/mg Protein) in Control $G_{I}$, Aflatoxicosed Untreated $G_{I I}$ and BHT $G_{I I I}$ and Copper Nicotinate $\mathbf{G}_{\mathrm{IV}}$ Aflatoxin Cotreated Rats

\begin{tabular}{|c|c|c|c|}
\hline Parameters in Hepatic Tissue & $\begin{array}{c}\text { Group I } \\
\text { (Control), } \mathbf{n = 1 5}\end{array}$ & $\begin{array}{c}\text { Group II } \\
\text { (AFB1), n=15 }\end{array}$ & $\begin{array}{c}\text { Group III } \\
\text { (AFB1+BHT),n=15 }\end{array}$ \\
\hline \hline lipid peroxide (nmol/g wt tissue) & $11.9 \pm 0.88$ & $38.94 \pm 2.03 * * *$ & $12.89 \pm 1.29 *$ \\
\hline GsPx (nmol/min/mg protein) & $280.5 \pm 2.33$ & $195.8 \pm 0.28^{* * *}$ & $260.3 \pm 2.65 *$ \\
\hline total thiols (nM/g protein) & $3.294 \pm 1.32$ & $1.026 \pm 1.53 * * *$ & $2.844 \pm 0.97 * *$ \\
\hline nitric oxide ( $\mu$ mol/g protein) & $151.2 \pm 0.39$ & $190.5 \pm 1.35^{* *}$ & $159.3 \pm 0.85$ \\
\hline GSH (nmol/mg protein) & $28.2 \pm 1.22$ & $18.1 \pm 0.48 * * *$ & $27.5 \pm 1.33$ \\
\hline GST (nmol/min/mg protein) & $430.3 \pm 03.98$ & $305.2 \pm 5.12^{* * *}$ & $146.8 \pm 1.03$ \\
\hline
\end{tabular}

Values are expressed as the mean \pm SE for (15) animals in each group.

$* \mathrm{p}<0.05 ; * * \mathrm{p}<0.01 ; * * * \mathrm{p}<0.001$ represent significant differences as compared to control animals (group I).

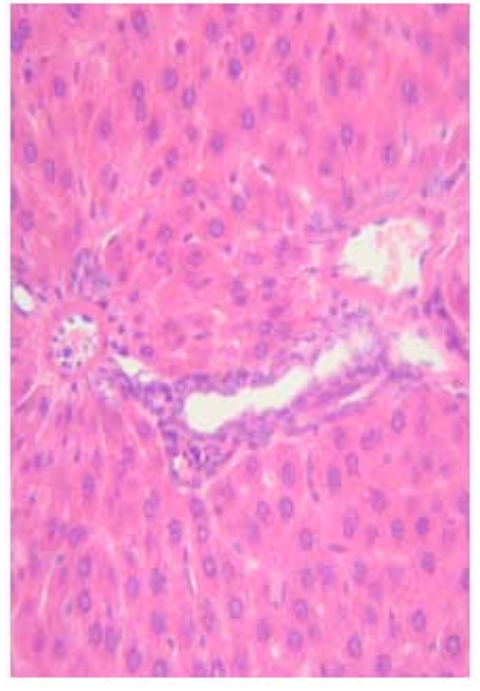

(a)

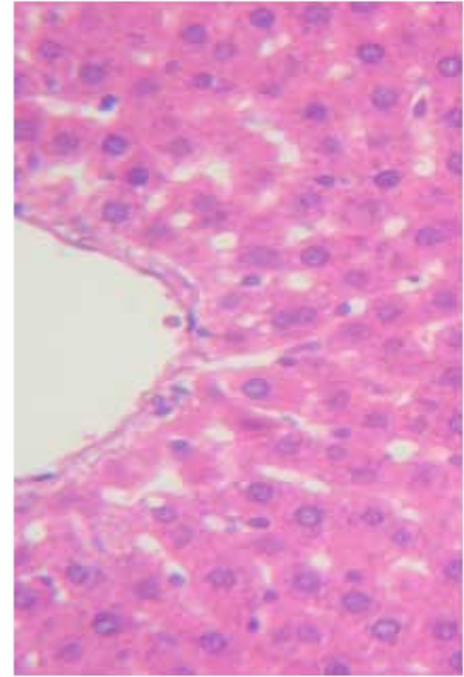

(b)

Fig (1). Stained sections with Heamatoxyllin and eosin for normal animals: (a \& b) show liver section of negative control animals that reveals normal liver architecture. (Hx. \& E. ×400).

normal; $\quad(\mathrm{p}<0.001)$. Serum nitric oxide concentrations $(\mu \mathrm{mol} / \mathrm{ml})$ : in Table $\mathbf{1}$, The $\mathrm{G}_{\mathrm{II}}$ showed dramatically significant increase higher than normal, $(\mathrm{p}<0.001)$. The level of serum nitric oxide concentration was non-significantly changed from normal in $\mathrm{G}_{\mathrm{III}}$ animals, $(\mathrm{p}<0.001)$. The $\mathrm{G}_{\mathrm{IV}}$ showed also non-significant lower value, $(\mathrm{p}<0.001)$. Hepatic tissue nitric oxide concentrations ( $\mu \mathrm{mol} / \mathrm{g}$ proteins): from Table 2, The $\mathrm{G}_{\mathrm{II}}$ liver $\mathrm{NO}$ was significantly elevated than normal $(p<0.01)$, While $\mathrm{G}_{\text {III }}$ was non-significantly higher than normal value $(\mathrm{p}<0.001)$. Similarly, the animals co-treated with $\mathrm{Cu}$-nicotinate complex; $\mathrm{G}_{\mathrm{IV}}$ changed to significant lower value. Serum superoxide dismutase (SOD) activity (U/ml): From Table 1, the aflatoxicosed untreated rats $\mathrm{G}_{\text {II }}$ showed significant lower than normal $(\mathrm{p}<0.01)$. The level of serum SOD was increased in $\mathrm{G}_{\mathrm{III}}$ non-significantly higher than (p>0.001). Aflatoxicosed animals with simultaneously cotreatment with $\mathrm{Cu}$-nicotinate complex $\mathrm{G}_{\mathrm{IV}}$ showed significantly higher than normal $(\mathrm{p}<0.001)$. Hepatic tissue glutathione peroxidase GsPx activity as $(\mathrm{nmol} / \mathrm{min} / \mathrm{mg}$ protein): From Table 2, it was found that the level of hepatic tissue GsPx was significantly lower than normal $(p<0.001)$. $\mathrm{G}_{\mathrm{III}}$ group exhibited improvement response that was significantly greater than normal $(\mathrm{p}<0.05)$. $\mathrm{G}_{\mathrm{IV}}$ showed signs of improvement which was non-significantly different from normal. Serum glutathione-S-transferase (GST) concentrations $(\mathrm{nmol} / \mathrm{min} / \mathrm{ml})$ : Table 1: $G_{\text {II }}$ aflatoxicosed without treatment showed remarkable reduction in serum GST value that was significantly different from normal $(p<0.001)$. $\mathrm{G}_{\text {III }}$ group showed more or less reduced level from the normal, that change was significant $(p<0.05) . \mathrm{G}_{\mathrm{IV}}$ showed improvement that was non-significant change from normal $(\mathrm{p}<0.001)$.

Hepatic tissue GST concentration $(\mathrm{nmol} / \mathrm{min} / \mathrm{mg}$ protein): it is seen from Table $\mathbf{2}, \mathrm{G}_{\mathrm{II}}$ that was a significant reduction in the enzyme activity than normal $(\mathrm{p}<0.001)$. $\mathrm{G}_{\text {III }}$ measurement showed improvement that was a significant change from normal $(\mathrm{p}<0.05) . \mathrm{G}_{\mathrm{IV}}$ animals measurement reflected great improvement that was non-significantly different from normal $(\mathrm{p}<0.01)$. Serum ceruloplasmine (mg/dl): Table 1 illustrates the level was dramatically reduction in $\mathrm{G}_{\mathrm{II}}$ that was a significant reduction from normal $(p<0.001) . G_{I I I}$ animals value that was non-significantly different from normal $(p<0.05)$. The $\mathrm{G}_{\mathrm{IV}}$ group exceeded the normal level to significantly greater value $(\mathrm{p}<0.01)$.

Histological Examination: Fig. (1) shows histological features of health control $\mathrm{G}_{\mathrm{I}}$ animals. Fig. (2a through e) shows 


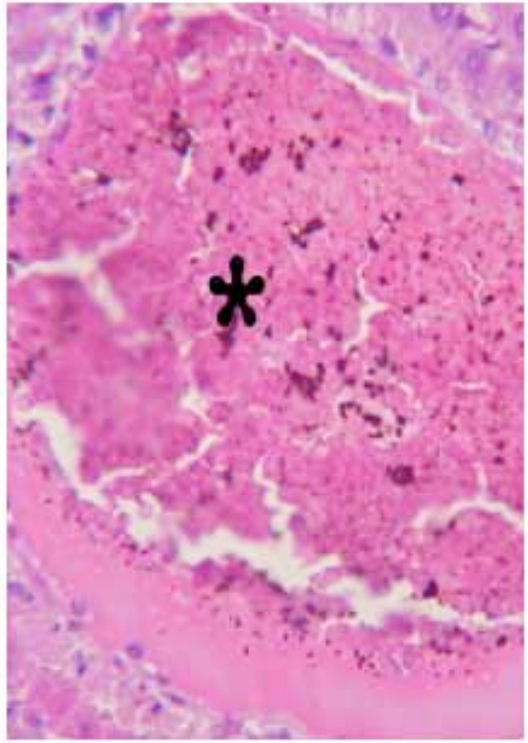

(a)

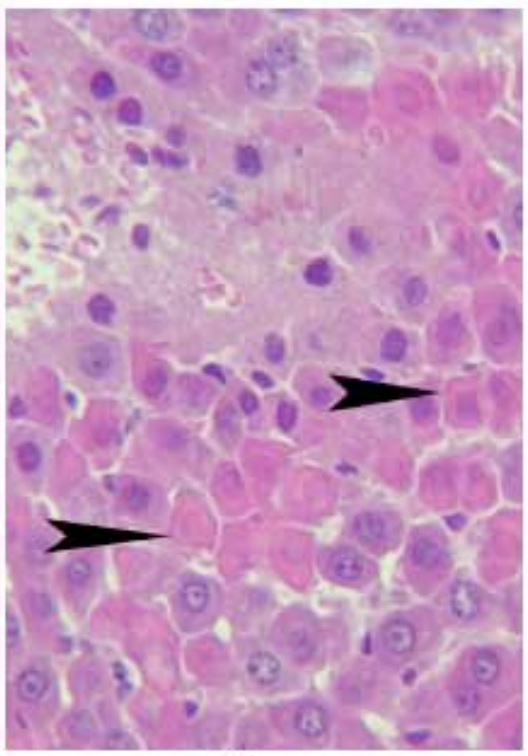

(b)

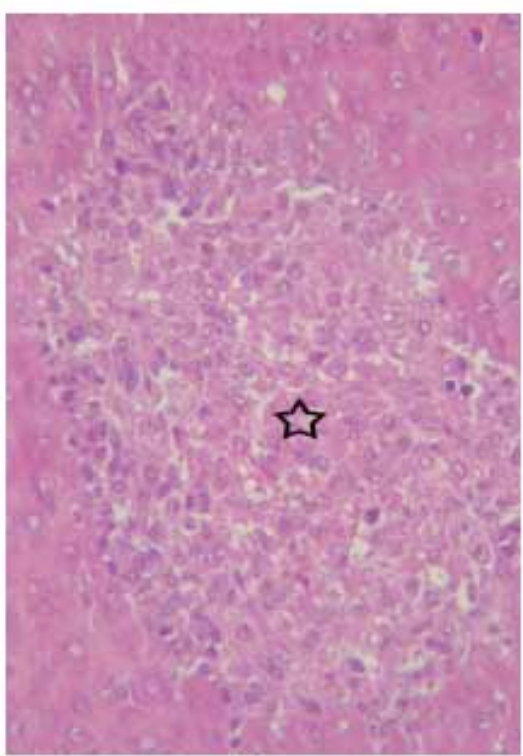

(c)

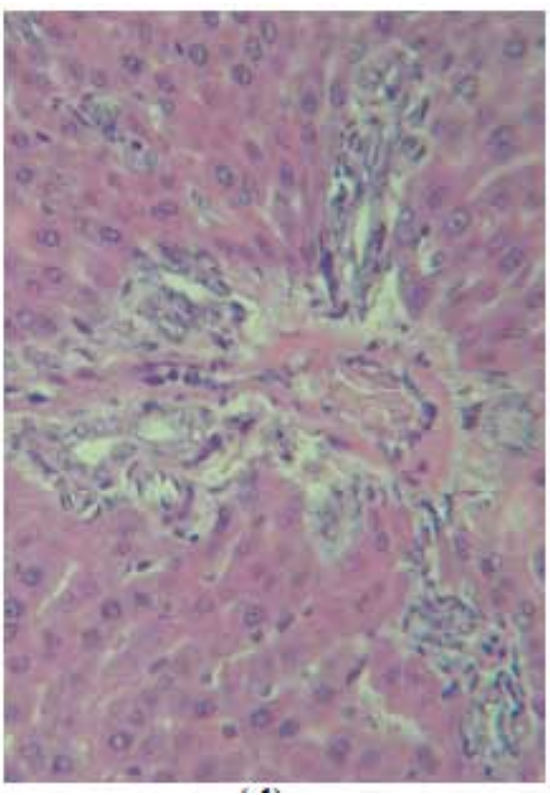

(d)

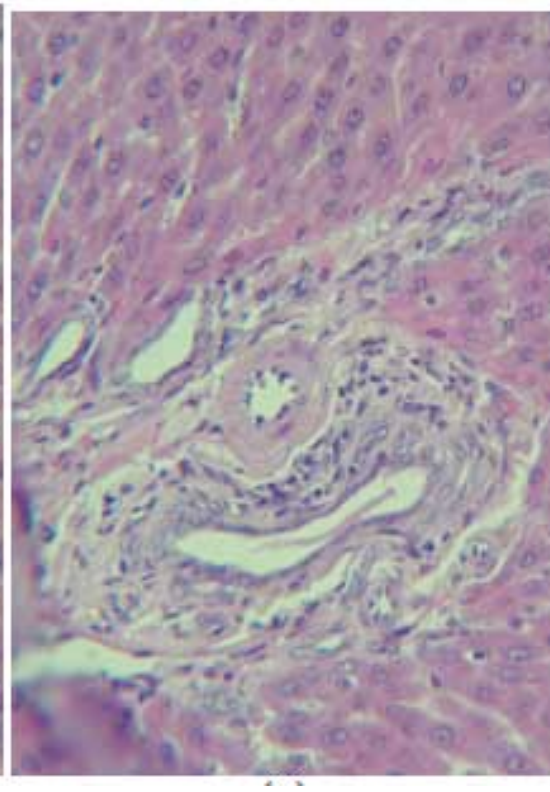

(e)

Fig (2). Stained sections with Heamatoxyllin and eosin for aflatoxicosed animals:

(a) Shows a liver section of $\mathrm{G}_{\mathrm{II}}$ animals with markedly dilated congested central vein occupied by large thrombus (star). Note that the multiple iron deposits in the field. (Hx. \& E. ×400).

(b) Shows liver focal hepatic necrosis (arrow head), predominantly perivascular with infiltration of the hepatic parenchyma by lymphocytes are characterized (Hx. \& E. ×400).

(c) Shows liver localized aggregation of cells (star); some appear with vesicular nuclei, others appear with dense nuclei and necrotic cells with vacuolated cytoplasm are also detected. (Hx. \& E. ×400).

(d) Shows a liver $\mathrm{G}_{\mathrm{II}}$ animals, bile ducts hyperplasia as well as mononuclear inflammatory cells formed mainly of lymphocytes, hyperplasia of kupffer cells (Hx. \& E. ×400)

(e) Shows a liver of $\mathrm{G}_{\mathrm{II}}$ group, the portal tracts are thickened by cell proliferation of bile ducts as well as mononuclear inflammatory cells formed mainly of lymphocytes, (Hx. \& E. ×400).

microscopic examination of aflatoxicosed livers of $\mathrm{G}_{\mathrm{II}}$ animals. The liver appeared with markedly dilated congested central vein occupied by large thrombus and multiple iron deposits as well as hepatic cellular necrosis (Fig 2a). Fig. (2b) shows liver focal hepatic necrosis (arrow head), predominantly perivascular with infiltration of the hepatic parenchyma by lymphocytes are characterized. Liver localized aggregation of cells (star); some appear with vesicular nuclei, others appear with dense nuclei and necrotic cells with vacuolated cytoplasm are also detected in Fig. (2c). In Fig. (2d), the same group liver of aflatoxicosed untreated $\mathrm{G}_{\mathrm{II}}$ animals, bile ducts exhibit hyperplasia as well 


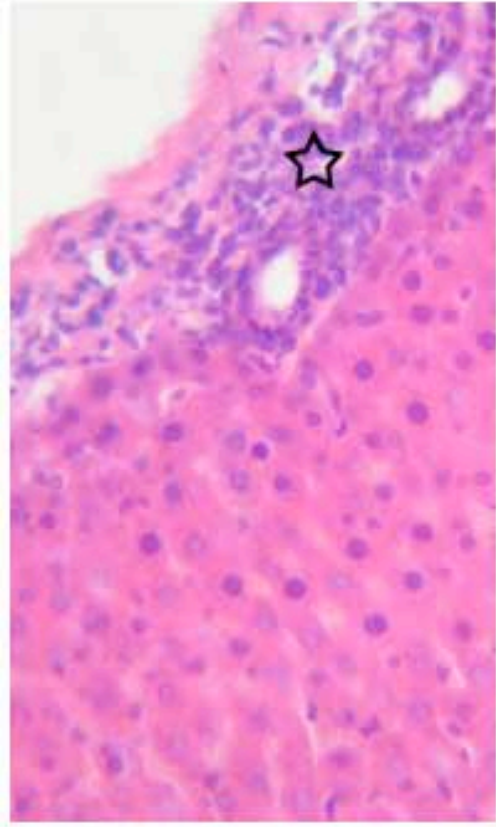

(a)

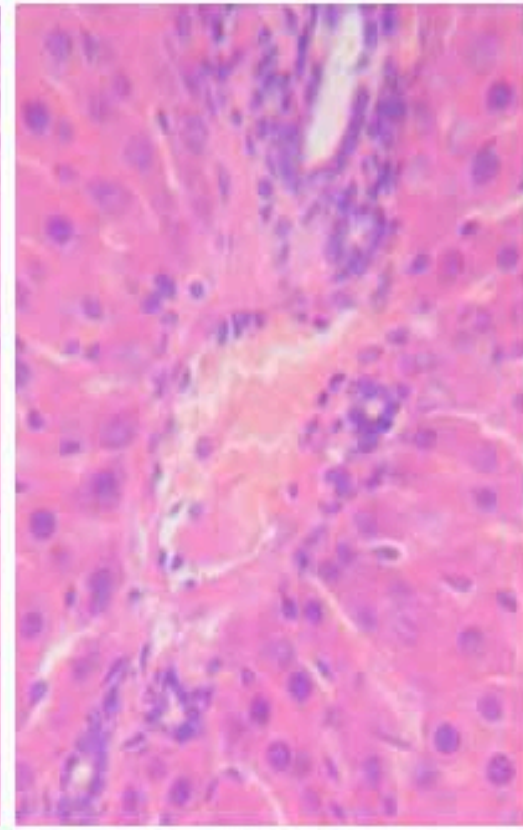

(b)

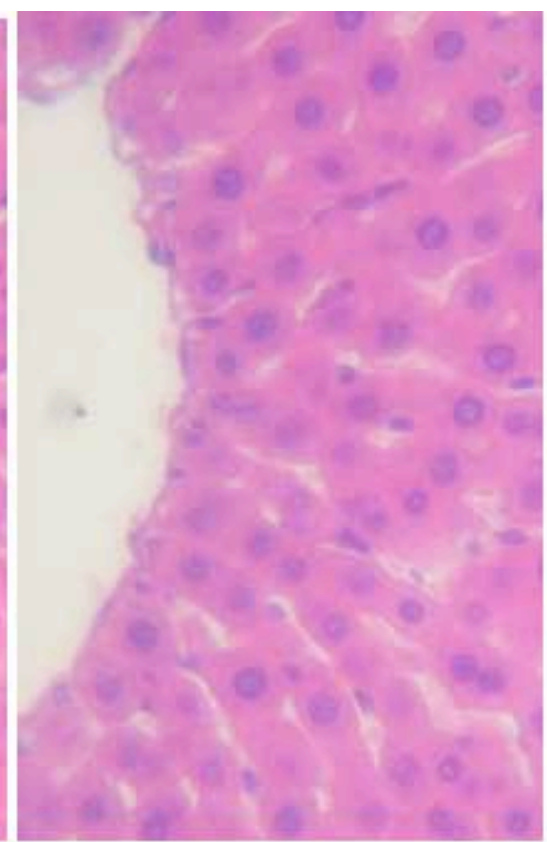

(c)

Fig (3). Stained sections with Heamatoxyllin and eosin for co-treated rats by BHT or copper(I)-nicotinate complex animals:

(a) A liver section of $\mathrm{G}_{\mathrm{III}}$ animals; perivascular infiltration of the hepatic parenchyma with lymphocytes (star), some hepatocytes exhibit vesicular nuclei others appear with dense nuclei (Hx. \& E. ×400).

(b) A liver section of $\mathrm{G}_{\mathrm{III}}$ a minimal cellular infiltration in the portal tract area, multiple small bile ducts are present hepatocytes more or less normal(Hx. \& E. ×400).

(c) Shows a liver of $\mathrm{G}_{\mathrm{IV}}$ group, prevention of the effect of AFB1 on the liver where hepatic architecture had almost normal appearance. (Hx. \& E. $\times 400)$.

as mononuclear inflammatory cells formed mainly of lymphocytes, the portal tracts appear thickened by cell proliferation of bile ducts as well as mononuclear inflammatory cells formed mainly of lymphocytes, Fig. (2e).

Fig. (3a), shows liver section of $\mathrm{G}_{\mathrm{III}}$ animals; perivascular infiltration of the hepatic parenchyma with lymphocytes (star), some hepatocytes exhibit vesicular nuclei others appear with dense nuclei, in Fig. (3b) of the same group, we find minimal cellular infiltration in the portal tract area, multiple small bile ducts are present, hepatocytes have more or less normal appearance. In Fig. (3c), of $\mathrm{G}_{\mathrm{IV}}$ group, remarkable modulation in the effect of $\mathrm{AFB}_{1}$ on the liver where hepatic architecture returned to normal appearance. Fig. (4a through d) shows cross sections of liver of all groups stained with Masson's trichrome for collagen fibers and it depicts; (a) liver of control animals $\mathrm{G}_{\mathrm{I}}$, where delicate collagen fibers are around central vein and portal tract. (b) Liver section of $\mathrm{G}_{\mathrm{II}}$ animals with markedly increased collagen fibers around portal tract (star). (c) Shows a liver section of $\mathrm{G}_{\mathrm{III}}$ animals, with reduced thickness collagen fibers around portal tract (star) (d) Seen modulation of the effect of $\mathrm{AFB}_{1}$ on the liver where reduction in the collagen fibers around portal tract in $\mathrm{G}_{\mathrm{IV}}$ animals comparison to those treated with $\mathrm{G}_{\mathrm{III}}$ group. Fig. (5a through d) shows liver sections of all groups stained with Prussian blue for detection of Iron deposits in tissue. (a) Shows a liver of negative control with normal appearance of liver parenchyma with no observed iron deposits, (b) Shows a liver section of $\mathrm{G}_{\mathrm{II}}$ animals, multiple iron deposits in the central vein. The liver section of GIII animals appeared without any observed iron deposits in the liver parenchyma, see Fig. (4c). while in Fig. (5d), G $\mathrm{G}_{\mathrm{IV}}$ liver section showed no signs of iron deposits in the central vein or liver parenchyma.

Fig. (3a), shows liver section of $\mathrm{G}_{\mathrm{III}}$ animals; perivascular infiltration of the hepatic parenchyma with lymphocytes (star), some hepatocytes exhibit vesicular nuclei others appear with dense nuclei, in Fig. (3b) of the same group, we find minimal cellular infiltration in the portal tract area, multiple small bile ducts are present, hepatocytes have more or less normal appearance. In Fig. (3c), of $\mathrm{G}_{\mathrm{IV}}$ group, remarkable modulation in the effect of $\mathrm{AFB}_{1}$ on the liver where hepatic architecture returned to normal appearance. Fig. (4a through d) shows cross sections of liver of all groups stained with Masson's trichrome for collagen fibers and it depicts; (a) liver of control animals $\mathrm{G}_{\mathrm{I}}$, where delicate collagen fibers are around central vein and portal tract. (b) Liver section of $\mathrm{G}_{\mathrm{II}}$ animals with markedly increased collagen fibers around portal tract (star). (c) Shows a liver section of $\mathrm{G}_{\mathrm{III}}$ animals, with reduced thickness collagen fibers around portal tract (star) (d) Seen modulation of the effect of $\mathrm{AFB}_{1}$ on the liver where reduction in the collagen fibers around portal tract in $\mathrm{G}_{\mathrm{IV}}$ animals comparison to those treated with $\mathrm{G}_{\mathrm{III}}$ group. Fig. (5a through d) shows liver sections of all groups stained with Prussian blue for detection of Iron deposits in tissue. (a) Shows a liver of negative control with normal appearance of liver parenchyma with no observed iron deposits, (b) Shows a liver section of $\mathrm{G}_{\mathrm{II}}$ animals, multiple iron deposits in the central vein. The liver section of GIII animals appeared without any observed iron deposits in the liver parenchyma, 


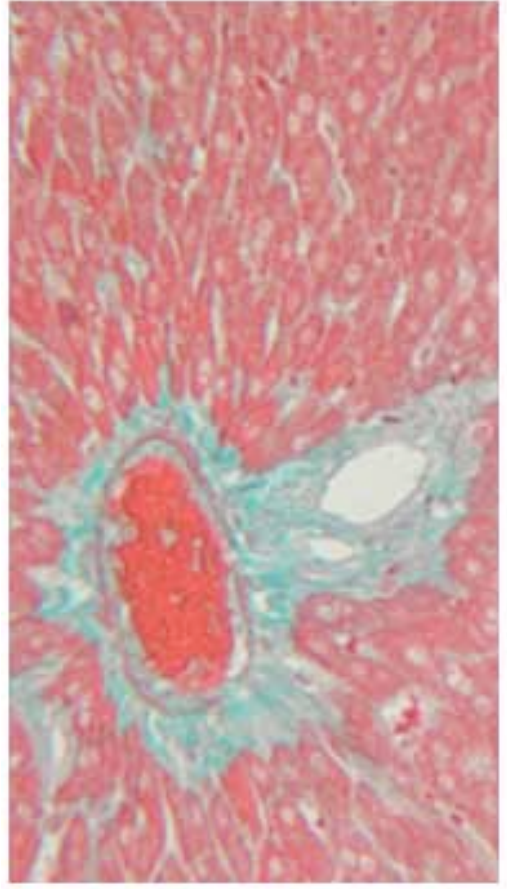

(a)

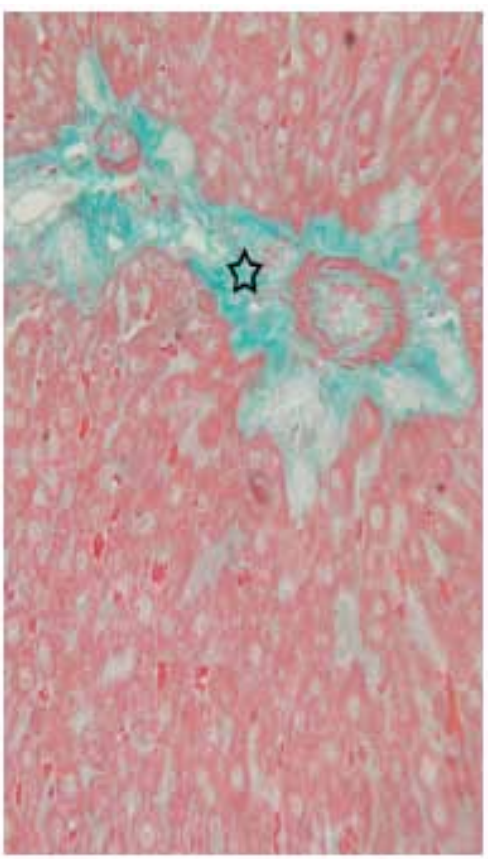

(c)

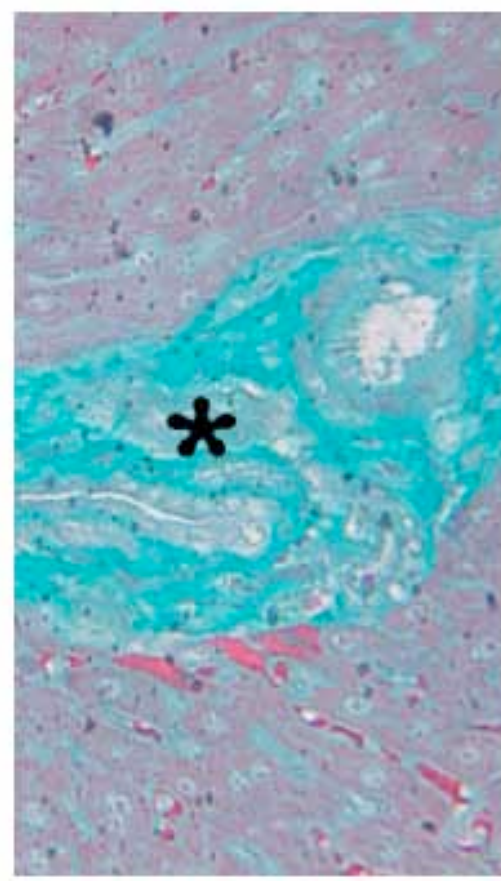

(b)

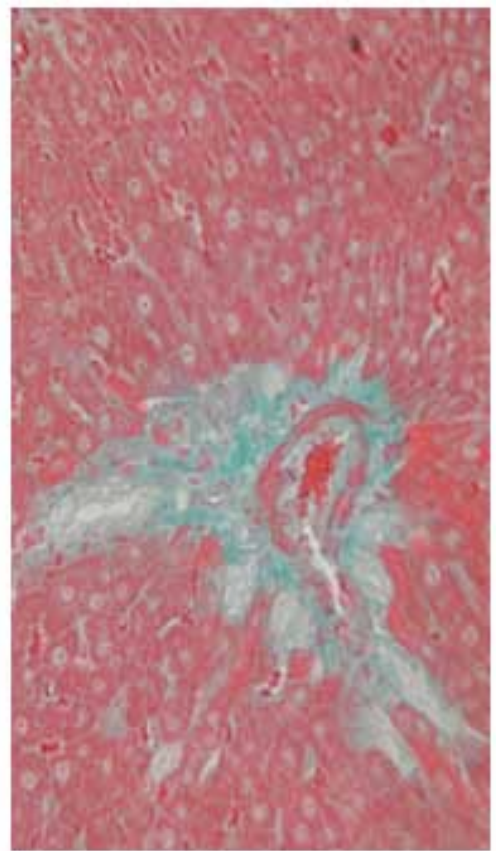

(d)

Fig (4). Stained sections with Masson's trichrome for normal control, aflatoxicosed, co-treated animals with BHT or copper(I)- nicotinate complex:

(a) Shows a liver of negative control animals where delicate collagen fibers are around central vein and portal tract (Masson trichrome $\mathrm{X}$ 400). (b) Shows a liver of aflatoxicosed animal for five weeks, the markedly increase in the collagen fibers around portal tract (star). (Masson trichrom $\mathrm{x} 400$ ).

(c) Shows a liver of aflatoxicosed animal for five weeks co-treated by BHT, with reduced collagen fibers around portal tract (star) (Masson trichrome $\times 400$ ).

(d) Shows a liver of aflatoxicosed animal for five weeks co-treated by copper(I)- nicotinate complex amelioration in the effect of $\mathrm{AFB}_{1}$ on the liver with reduction in the collagen fibers around portal tract in comparison to those treated with BHT group (Masson trichrome $\times 400)$. 


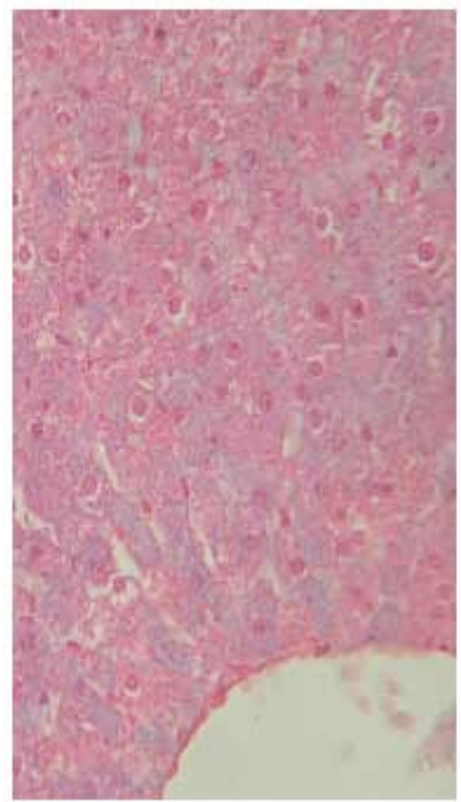

(a)

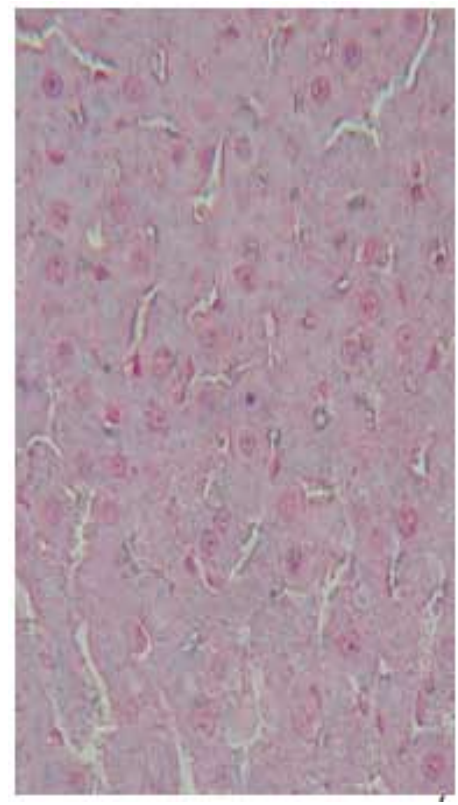

(c)

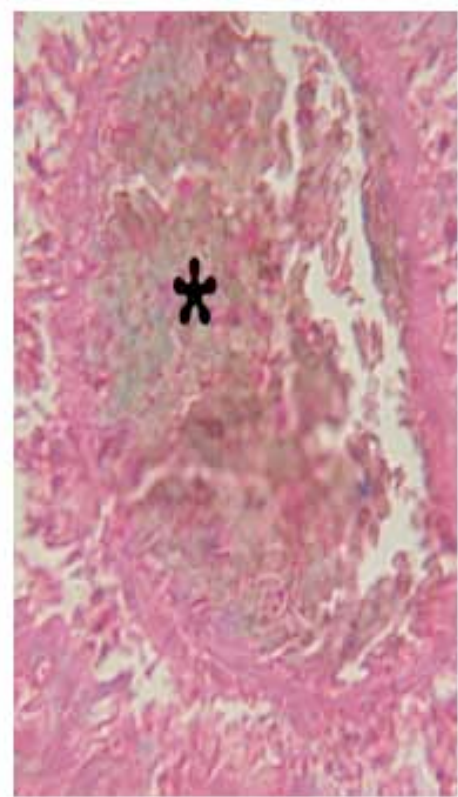

(b)

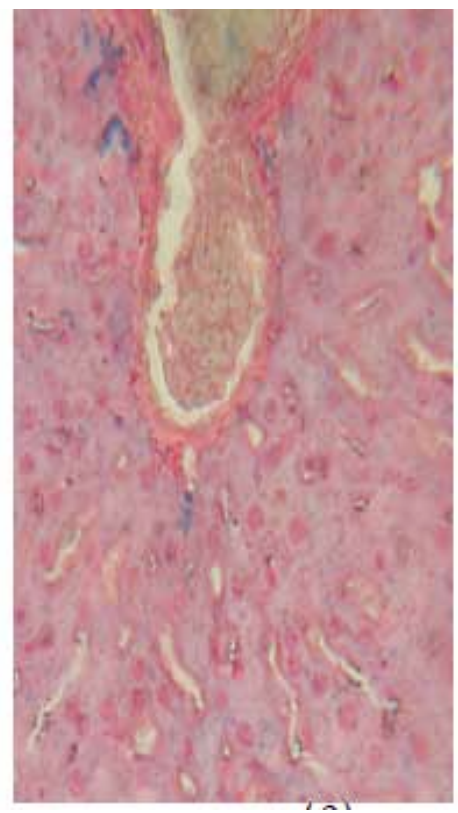

(d)

Fig (5). Stained sections with Prussian blue for normal control, aflatoxicosed,co-treated animals with BHT or copper(I)- nicotinate complex: (a) Shows a liver of negative control animal of normal looking appearance of liver parenchyma with no observed iron deposits. (Prussian blue stain X 400) (b) Shows a liver of aflatoxicosed animal for five weeks multiple iron deposits in the central vein (star). (Prussian blue stain X 400). (c) Shows a liver of aflatoxicosed animal for five weeks co-treated by BHT without any observed iron deposits in the liver parenchyma (Prussian blue stain $\times 400$ ). (d) Shows a liver of aflatoxicosed animal for five weeks co-treated by copper(I)- nicotinate complex, no signs of iron deposits in the central vein or liver parenchyma (Prussian blue stain $\times 400$ ).

see Fig. (4c). while in Fig. (5d), G $\mathrm{GV}_{\mathrm{IV}}$ liver section showed no signs of iron deposits in the central vein or liver parenchyma.

\section{DISCUSSION}

The assayed biochemical parameters in circulating systemic blood as well as hepatic tissue homogenates were in consistency with those findings of the microscopic examination characters. The total serum protein or serum albumin levels were highly reduced by aflatoxicosis due to inhibition of protein synthesis in hepatic tissue and other organs $[35,36]$. The antioxidant BHT prevented such reduction in protein synthesis due to chemoprevention of aflatoxin $B_{1}$ metabolism in biological systems [37]. Similarly, treatment with copper nicotinate complex showed improvement that confers a hepato-cellular protective as well as antioxidant effect of copper (I) nicotinate complex [1819]. Concomitantly, the changes in transaminases gave a positive sign for the protective effect of either BHT or the copper (I)-nicotinate complex against hepatic tissue collapse by aflatoxicosis. Elevated levels of measured hepatocellular 
oxidative stress markers (NO and lipid peroxide) were prominent by aflatoxicosis [38]. Co-treatment by either BHT or copper nicotinate complex that reduced such biochemical parameters indicates that both of them are real able hepatocellular protective agent.

Reduction of accumulated levels NO and lipid peroxides in hepatic tissue by BHT and the copper complex cotreatment that was regulated and promoted by elevation of antioxidant cellular chemicals such as GSH and total thiols [39], this could be attributed frankly to the antioxidant effect of BHT [20, 40] and the cellular protective antioxidant $\mathrm{Cu}(\mathrm{I})$ - nicotinate complex [41]. Since, induction of protective GST has been posited possible chemoprotective mechanism by BHT and other phenolic antioxidant as enzyme promoters has been confirmed before by Hayes et al., (1996)[42]. Herein, results could be rationally accepted. Inasmuch as parallel enzymatic induction for the GSTmediated detoxificating enzyme against AFB1 by using the copper (I)- nicotinate complex, in this study is the first time to be deduced. The blood circulating levels of such parameters that were parallel to those of hepatic tissue could be interpreted similarly due to the antioxidant character of BHT and the predicted cellular protectant anti-inflammatory and antioxidant effect of the $\mathrm{Cu}(\mathrm{I})$-nicotinate complex on the cellular levels.

Since, aflatoxicosis is among the widely encountered features of environmental pollution that deteriorates the hepatic tissue; induction of aflatoxicosis in the tested experimental animals was associated with cellular damage that was characterized by, focal hepatic necrosis and increased collagen fibers around central vein and portal tract as it was detected by microscope. These characters were mostly absent by co-treatment with BHT. These findings are simply accepted due to pervious success of the use of BHT in preventing aflatoxicosis [43]. In addition, these cellular improving characters were microscopically obvious by utilization of the copper complex under consideration as a protective agent. This improvement was predicted since this complex has been confirmed previously as a therapeutic agent against induced non-alcoholic fatty liver in experimental animals [20].

Herein, after ingestion, AFB1 might be converted into its epoxide or the epoxide of its major metabolites AFM1 and these derivatives produced DNA adducts causing DNA strand breaks and point mutations [44]. Under this pathological condition, the active process of cellular self destruction, apoptosis may occur. The MDA is the end product of lipoperoxydation, considered as a late biomarker of oxidative stress and cellular damage $[45,46]$. Hence, the aflatoxicosed animals that were characterized by a marked increase in MDA level in the liver (Table 2), the oxidative damage is considered to be the main mechanism leading to the subsequent hepatotoxicity as it was reported before [47]. Protective activity of the antioxidant Thymoquinone (TQ) also was evaluated in a similar study against liver toxicity induced by AFB1 in mice. The serum levels of hepatic enzymes primarily reflect the degree of liver damage and have been commonly used as a diagnostic marker for hepatotoxicity. As shown in Table 1, AFB1 significantly elevated, AST and ALT which is in agreement with results of other studies [48, 49]. This finding is consistent within histopathological examination in which necrosis and degeneration, hyperplasia of kupffer cells and infiltration of mononuclear cells in liver sections that were observed. BHT prevented the histopathological changes as well as those co-treated by the copper complex decreased the number of inflammatory cells that was in parallel to the biochemical findings. However cotreatment with the copper (I) nicotinate complex initiated complete amelioration of the AFB1 associated changes where the liver tissues looked more or less similar to those of control. Markedly increase in the collagen fibers around portal tract in aflatoxin intoxicated animals in the present study are similar to those previously described for aflatoxicosis [50, 51] especially that was published by Bastianello et al., (1987)[50] who described the pathology of acute, subacute, and chronic aflatoxicosis. In this review the subacute form was typically characterized by extensive bile ductule hyperplasia with varying degrees of fibrosis and bridging fibrosis [50, 52, 53]. Typically, the chronic form was also characterized by extensive fibroplasia. Additionally, observed severe bile ductule proliferation and visible regenerative hepatocellular nodules could be frankly defined [50] as it was reported. BHT cotreated animals in this study exhibited reduced collagen fibers around portal tract, while animals co-treated by copper(I)- nicotinate complex exhibited amelioration in the effect of AFB1 on the liver with complete reduction in the collagen fibers around portal tract in comparison to those treated with BHT group. The current study shows that, induced aflatoxicosis dramatically reduced the level of the main blood circulating enzymatic free radical scavenger SOD, which was previously confirmed by others $[54,55]$. Such a reduction was elevated and normalized by the antioxidant co-treating agents BHT or the copper nicotinate complex. Notably, the copper complex was significantly more potent than that of the co-treating BHT. This prominent observation could be attributed to the biochemical behavior of the copper complexes that was confirmed to be similar to the SOD activities such as $\mathrm{Cu}(\mathrm{II})(3,5$-diisopropylsalicylic acid)2 (CuDIPS) [56], $\mathrm{Cu}$ (II) histidine complexes [57], $\mathrm{Cu}$ (II) complexes of macrocyclic polyamine derivatives [58], Bis(2,9-dimethyl-1,10-phenaanthroline)- $\mathrm{Cu}(\mathrm{I})$ nitrate $(\mathrm{Cu}(\mathrm{I})$ (DMP)2) [59] and $\mathrm{Cu}(\mathrm{II})$-oligopeptide [60].

Similarly, the blood ceruloplasmin that was highly consumed by aflatoxicosis was improved by association of the co-treatment of the anti-inflammatory agents BHT or the tested copper-nicotinate complex. The latter was also highly significantly more effective than that of the BHT. It is worthy noted that ceruloplasmine is one of the acute phase transport proteins and that after intoxication; copper and zinc are depleted and tend to leave the body with urine, this depletion of copper may be a causative parameter for the decrease of ceruloplasmine [61].

\section{CONCLUSION}

Basically, these obtained results by using cpper (I)nicotinate complex as a profelactive therapeutic agent against aflatoxicosis not only acts like BHT but also it was more prominently effective on measured parameters and biologically saver as food additive than the synthetic BHT.

\section{CONFLICT OF INTEREST}

The authors confirm that this article content has no conflicts of interest. 


\section{ACKNOWLEDGEMENT}

Declared none.

\section{REFERENCES}

[1] Meggs WJ. Epidemics of mold poisoning past and present. Toxicol Ind Health 2009; 25(9-10): 571-6.

[2] Smela ME, Currier SS, Baily EA, Essigmann JM. The chemistry and biology of aflatoxin $\mathrm{B}_{1}$ : from mutational spectrometry to carcinogenesis. Carcinogenesis 2001; 22(4): 535-45.

[3] Wang JS, Groopman JD. DNA damage by mycotoxins. Mutat Res 1999; 424 (1-2): 167-81.

[4] Nassar AY, Megalla SE, Abd El-Fattah HM, Hafez AH, El-Deap TS. Binding of aflatoxin $B_{1}, G_{1}$ and $M$ to plasma albumin. Mycopathologia 1982; 79: 35-8

[5] Ch'ih JJ, Delvin TM. The distribution and intracellular translocation of aflatoxin $\mathrm{B}_{1}$ in isolated hepatocytes. Biochem Biophys Res Commun 1984; 122: 1-8.

[6] Chu FS. Mycotoxins: food contamination, mechanism, carcinogenic potential and preventive measures. Mutat Res 1991; 259: 291-306.

[7] Hsu IC, Metcalf RA, Sun T, Welsh JA, Wang NJ, Harris CC. Mutational hotspot in the p53 gene in human hepatocellular carcinomas. Nature 1991; 350: 427-8.

[8] Hocman G. Chemoprevention of cancer: phenolic antioxidants (BHT, BHA). Int J Biochem 1988; 20: 639-51.

[9] Larsen C, Ehrich M, Driscoll C, Gross WB. Aflatoxin-antioxidant effects on growth of young chicks. Poult Sci 1985; 64: 2287-91.

[10] Singletary KW. Effect of dietary butylated hydroxytoluene on the in vivo distribution, metabolism and DNA-binding of 7,12dimethylbenz [a] anthracene. Cancer Lett 1990; 49: 187-93.

[11] Hayes JD, Judah DJ, McLellan LI, Neal GE. Contribution of the glutathione S-transferases to the mechanisms of resistance to aflatoxin $B_{1}$. Pharmacol Ther 1991; 50: 443-72.

[12] Monroe DH, Holeski CJ, Eaton DL. Effect of single-dose and repeated dose pretreatment with 2(3) tert-butyl-4-hydroxyanisole (BHA) on the hepatobiliary disposition and covalent binding to DNA of aflatoxin $B_{1}$ in the rat. Food Chem Toxicol 1986; 24: 1273-81.

[13] Monroe DH, Eaton DL. Comparative effects of butylated hydroxyanisole on hepatic in vivo DNA binding and in vitro biotransformation of aflatoxin $\mathrm{B}_{1}$ in the rat and mouse. Toxicol Appl Pharmacol 1987; 90: 401-9.

[14] Penning TM. Chemical Carcinogenesis. Chapter 8. In: Milenda S, Yates, Kensler TW, Eds. Detoxication of Chemical Carcinogens and Chemoprevention. $1^{\text {st }}$ ed. N Y: Humana Press 2011.

[15] Mandel HG, Manson MM, Judah DJ, et al. Metabolic basis for the protective effect of the antioxidant ethoxyquin on Aflatoxin in $\mathrm{B}_{1}$ hepatocarcinogenesis in the rat. Cancer Res 1987; 47: 5218-23.

[16] Sorenson JRJ, Ed. Biology of copper complex. New Jersey: Human Press 1987; pp. 3-9.

[17] Musa SA, Hafez AH, Nassar AY, Gohar MA. Copper (I) nicotinic acid complex: An immunopoptentiator in chickens vaccinated against New Castle diease. In: Sorenson JRJ, Ed. Biology of copper complexes. NJ: Humana Press 1987; pp. 343-50.

[18] EL-Saadani MA, Nassar AY, Soad H, Abou E-A, Metwally TH, Mafdy AM. The protective effect of copper complexes against gastric mucosal ulcer in rats. Biochem Pharmacol 1993; 46: 10118.

[19] El-Saadani MA. A combination therapy with copper nicotinate complex reduces the adverse effects of 5-flourouracil on patients with hepatocellular carcinomas. J Exp Oncol 2004; 4: 19-24.

[20] Salama RH, Nassar AY, Nafady AA, Mohamed HH. A novel therapeutic drug (copper nicotinic acid complex) for non- alcoholic fatty liver. Liver Int 2007; 27(4): 454-64.

[21] Williams GM, Iatropoulos MJ. Inhibition of the hepatocarcinogenicity of aflatoxin $B_{1}$ in rats by low levels of the phenolic antioxidants butylated hydroxyanisole and butylated hydroxytoluene. Cancer Lett 1996; 104: 49-53.

[22] Gohar M, Dratovsky M. Synthesis and infrared examination of copper (I) halid complex with nicotinic acid and its ethyl ester. Coll Czech Chem Commun 1975; 40: 26-32.

[23] Weichselbaum TE. Quantitative determination of serum protein. Am J Clin Pathol 1946; 7: 40.

[24] Van Bezooijen RL, Que I, Ederveen AG, Kloosterboer HJ, Papapoulos SE, Lowik CW. Plasma nitrate + nitrite level are regulated by ovarian steroids but do not correlate with trabecular bone mineral density in fats. J Endocrinol 1998; 159: 27- 34.

Ellman GL. Tissue sulfhydryl groups. Arch Biochem Biophys 1959; 82(1): 70-7.

[26] Misra H, Fridovich I. The role of superoxide anion in the autooxidation of epinephrine and a simple assay for superoxide dismutase. J Biol Chem 1972; 247(10): 3170-5.

[27] Beutler E, Duron O, Kelly BM. Improvement method for the determination of glutathione in tissue homogenate. J Lab Clin Med 1963; 61: 882-8.

[28] Jakoby WB. Enzymatic basis of detoxication. NY: Academic Press 1980.

[29] Mannervik B. The isozymes of glutatione transferase. Adv Enzymol Relat Areas Mol Biol 1985; 57: 357-417.

[30] Sunderman FW Jr, Nomoto S. Measuement of human serum ceruoplasmine by its p-phenylinediamine oxidase activity. Clin Chem 1970; 16(11): 903-10.

[31] Tappel L, Zalkin H. Inhibition of lipid peroxidation in mitochondria by vitamin E. Arch Biochem Biophys 1959; 80: 3336.

[32] Wang Q, Liao QK. Effect of nitric oxide on iron metabolism in rats with anemia of chronic disease. J Exp Hematol 2003; 11(4): 385-9

[33] Wang Y, Zhou Q, Wang S, Zhang J. Homocysteine-induced apoptosis of endothelial cell and its antagonism by folic acid-the roles of caspase3, c-IAP1 and c-IAP2. Wei Sheng Yan Jiu 2004; 33(3): 310-3.

[34] Drury R, Wallington EA. Carleton.s histological techniques. $5^{\text {th }}$ ed. UK: Oxford University Press 1980

[35] Sharma RP. Immunotoxicity of mycotoxins. J Dairy Sci 1993; 76 : 892-7.

[36] Abdel-Wahhab MA, Nada SA, Khalil FA. Physiological and toxicological responses in rats fed aflatoxin- contaminated diet with or without sorbent materials. Anim Feed Sci Tech 2002; 97: 209-19.

[37] Guarisco JA, Hall JO, Coulombe RA Jr. Mechanisms of butylated hydroxytoluene chemoprevention of aflatoxicosis- inhibition of aflatoxin B1 metabolism. Toxicol Appl Pharmacol 2008; 227: 33946.

[38] Vijaya R, Ravindran J, Sachdanandam P, Shanthi P. Potential antioxidant role of tridham in managing oxidative stress against aflatoxin-B1-induced experimental hepatocellular carcinoma. Int J Hepatol 2012; 2012: 428-373

[39] Bounous G. Why protein concentrate (WPC) and glutathione modulation in cancer treatment. Anticancer Res 2000; 20(6c): 478592.

[40] Bertinato J, Abbe MRL. Copper modulates the degradation of copper chaperone for $\mathrm{Cu}, \mathrm{Zn}$ superoxide dismutase by the $26 \mathrm{~S}$ prtoesome. J Biol Chem 2003; 278: 35071-8.

[41] El-Metwally TH, El-Salahy MB, Tourket MJ, Ali A-K, Abdul Haleem A-HA, Hassan K-HA. Apoptotic markers, VEGF and TGF-levels in the gastric ulceration "Shay rats" model: towards a commonplace mechanism of action for copper-glycinate and nicotinate complexes. Arab J Lab Med 2009; 35(3): 29.

[42] Hayes JD, McLeod R, Ellis EM, et al. Regulation of glutathione Stransferases and aldehyde reductase by chemoprotectors: studies of mechamisms responsible for inducible resistance to aflatoxin B1. IARC Sci Publ 1996; 139: 175-87.

[43] Klein PJ, Van Vleet TR, Hall JO, Coulombe RA. Dietary butylated hydroxytoluene protects against aflatoxicosis in Turkeys. Toxicol Appl Pharmacol 2002; 182: 11-9.

[44] Eaton DL, Gallagher EP. Mechanisms of aflatoxin carcinogenesis. Annu Rev Pharmacol Toxicol 1994; 34: 135-72.

[45] Kim HS, Kwack SJ, Lee BM. Lipid peroxidation, antioxidant enzymes, and benzo[a]pyrene-quinones in the blood of rats treated with benzo[a]pyrene. Chem Biol Interact 2000; 127: 139-50.

[46] Dotan Y, Lichtenberg D, Pinchuk I. Lipid peroxidation cannot be used as a universal criterion of oxidative stress. Prog Lipid Res 2004; 43: 200-27.

[47] Amici M, Cecarini V, Pettinari A, et al. Binding of aflatoxins to the 20S proteasome: effects on enzyme functionality and implications for oxidative stress and apoptosis. Biol Chem 2007; 388: 107-17.

[48] Shyamal S, Latha PG, Suja SR, et al. Hepatoprotective effect of three herbal extracts on aflatoxin B1-intoxicated rat liver. Singapore Med J 2010; 51: 326-31.

[49] Hong LU, Yan LI. Effects of bicyclol on aflatoxin B1 metabolism and hepatotoxicity in rats. Acta Pharmacol Sin 2002; 23: 942-5. 
[50] Bastianello SS, Nesbit JW, Williams MC, Lange AL. Pathological findings in a natural outbreak of aflatoxicosis in dogs. Onderstepoort J Vet Res 1987; 54: 635-40.

[51] Ketterer PJ, Williams ES, Blaney BJ, Connole MD. Canine aflatoxicosis. Aust Vet J 1975; 51: 355-7.

[52] Hyde W, Kiesey J, Ross PF, Stahr HM. General gas chromatography: analytical methods of toxicology. New York: John Wiley and Sons Inc 1977; pp. 104-6.

[53] Kelly RW. Liver and biliary system. In: Jubb KVF, Kennedy PC, Palmer N, Eds. Pathology of domestic animals. $4^{\text {th }}$ ed. Canada: Academic Press 1990; vol. 2: pp. 389-90.

[54] Abdel- Wahhab MA, Said A, Huefner A. NMRand radical scavenging activities of patuletin from Urtica urens against aflatoxin B1. Pharmacol Biol 2005; 43(6): 515-25.

[55] Abdel- Wahhab MA, Omara EA, Abdel-Galil MM, Hassan NS, Nada SA, ElSayed M. M. Zizyphus Spina-Christi extract protects against aflatoxin B1 initiated hepatic carcinogenicity. Afr J Tradit Complement Altern Med 2007; 4(3): 248-56.
[56] Kensler TW, Trush M. Inhibition of oxygen radical metabolism in phorbol esteractivated polymorphonuclear leukocytes by an antitumor promoting copper complex with superoxide dismutasemimetic activity. Biochem Pharmacol 1983; 32: 3485-7.

[57] Weinstein J, Bielski BHJ. Reaction of superoxide radical with copper (II)-histidine complexes. J Am Chem Soc 1979; 102: 49169.

[58] Kimura E, Sakonaka A, Nakamoto M. Superoxide dismutase activity of macrocyclic polyamine complexes Biophys Acta 1981; 678: 172-9.

[59] Bijloo GJ, Goot H, Bast A, Timmerman H. Copper complexes of 1,10- phenanthroline and related compounds as superoxide dismutase mimetics. J Inorg Biochem 1990; 40: 237-44.

[60] Ueda J, Ozawa T, Miyazaki M, Fujiwara Y. Activation of hydrogen peroxide by coppper (II) complexes with some histidine-containing peptides and their SOD-like activities. J Inorg Biochem 1994; 55: 123-30.

[61] Berger M, Cavadini C, Bart A. Cutaneous copper and zinc losses in burns. Burns 1992; 18(5): 373-80.

Received: October 30, 2012

Revised: January 02, 2013

Accepted: January 03, 2013

(c) Shatat et al.; Licensee Bentham Open.

This is an open access article licensed under the terms of the Creative Commons Attribution Non-Commercial License (http://creativecommons.org/licenses/bync/3.0/), which permits unrestricted, non-commercial use, distribution and reproduction in any medium, provided the work is properly cited. 